\title{
Assessment of the level of contamination of feed with micromycetes and mycotoxins in the cattle industry of Ukraine in recent years
}

\author{
Kutzan O. ${ }^{1}$, Orobchenko O. ${ }^{2}$, Yaroshenko M. ${ }^{3}$, Gerilovich I. ${ }^{4}$ \\ NSC «Institute for Experimental and Clinical Veterinary Medicine» \\ 83 Pushkinska Str., Kharkiv, 61023, Ukraine \\ e-mail: ${ }^{1}$ okutsan@ukr.net, ${ }^{2 t o x i-l a b @ u k r . n e t,{ }^{3} \text { margarita.yaroshenko.69@ukr.net, }{ }^{4} a n t i r a @ u k r . n e t ~}$ \\ ORCID: ${ }^{1}$ 0000-0002-5898-3420, ${ }^{2} 0000-0002-0885-7776,{ }^{3} 0000-0001-9040-6474,{ }^{4} 0000-0002-6742-2086$
}

Goal. To study the degree of contamination, the species of micromycetes and the content of mycotoxins (aflatoxin B1, sterigmatocystin, zearalenone, patulin) in feed for cattle for 2018 and the first half of 2019 and to carry out a retrospective analysis of contamination of feed with micromycetes over the last 5 years. Methods. Mycological and micotoxicological study was conducted in accordance with generally accepted and developed in the laboratory of Toxicological monitoring methods of determination. Results. Level of contamination with micromycetes in 87 samples of feed for cattle in 2018-2019 exceeded the maximum permissible level (MPL) in $73.6 \%$ of samples. The major ones were: feed $-23,4 \%$, mono feeds and silage $-18,7 \%$ each, straw $-10,9 \%$, and hay $-7.8 \%$. The main pollutants of the feed were micromycetes of the family Mucoraceae $-25.6 \%$, and of species: Aspergillus Mich. - 24,7, Penicillium Linc. 9.5, Fusarium Linc. - 3.3, other - 36.9\%. 35 samples of feed were examined on the presence of mycotoxins. Only one sample of feed has zearalenone $(0,88 \mathrm{mg} / \mathrm{kg}$, which is $76 \%$ higher than MPL). Aflatoxin B1, sterigmatocystin, patulin and zearalenone were outside the method definition, and did not exceed MPL. Conclusions. The level of contamination with micromycetes of feed for cattle in 2018 and the first half of 2019 remained high, including poor quality (higher than MPL), and was $73.3 \%$ and $73.8 \%$ respectively. The main pollutants of the feed were moldy saprophytes of family Mucoraceae $-25.6 \%$, and species: Aspergillus Mich. - 24,7\%, Penicillium Linc. - 9.5\%, Fusarium Linc. - 3.3\%, other - 36.9\%. The presence of aflatoxin B1, sterigmatocystin, patulin and zearalenone in quantities higher than MPL in 34 samples of feed was fixed. Only in the sample of feed zearalenone was determined $-0,88 \mathrm{mg} / \mathrm{kg}$ of feed, which is $76 \%$ higher than MPL.

Key words: biotic contaminants, toxin-forming mold saprophytes, microscopic fungi strains.

DOI: https://doi.org/10.31073/agrovisnyk202002-08

One of the many negative environmental factors that affect the safety of feed materials and feeds are micromycetes and their secondary metabolites - mycotoxins. Their special danger lies in the latent form of impact on animal health. The presence of microscopic fungi in feed leads to a decrease in their consumption due to the deterioration of organoleptic qualities and causes a decrease in the absorption of nutrients and metabolic disorders in the body.

As a result, the costs of treatment of animals, as well as due to shortages and reduced quality of livestock products cause great economic losses [1-7]. According to the Food and Agriculture Organization of the United Nations (FAO), due to the high prevalence of microscopic fungi in almost all habitats and their high adaptive properties, mold saprophytes affect $25-40 \%$ of feeds each year [2]. Therefore, we believe that the systematic control of micromycetes and their secondary metabolites in feed at all stages of their manufacture and during storage is one of the main measures to prevent their negative impact on animal health and ensure the production of safe and quality products $[4,6,7]$.

The purpose of the work is to investigate the degree of contamination, species affiliation of micromycetes and the content of mycotoxins (aflatoxin B1, sterigmatocystin, zearalenone, patulin) in the feeds used in the livestock industry of Ukraine in 2018 - the first half of 2019 and

to compare the results with previous years.

Materials and methods. The study was conducted on the basis of the laboratory for toxicological monitoring of the NSC "IECVM" in the period 2018 - I half of 2019. We analyzed 87 samples of feed for dairy cattle from different regions of Ukraine: Kharkiv, Sumy, Odesa, Donetsk, Kyiv, Poltava, Cherkasy, Kirovograd, IvanoFrankivsk and Ternopil regions.

Mycological studies of the samples were performed according to generally accepted methods, in particular: the degree of contamination of feed with microscopic fungi was determined by the number of colony-forming units (CFU) per $1 \mathrm{~g}$ of feed under primary seeding in nutrient medium (agar wort and Chapek) [7, 8]; species affiliation of isolates of microscopic fungi was determined by comparing cultural and morphological characteristics of the isolated mycobiota (features of crop growth on different nutrient media, their size, shape, width, structure of edges and center of colonies, growth intensity, surface characteristics, colony color, their reverse, mycelium, etc. .) with the descriptions given in the determinants of micromycetes, and with museum strains of test cultures (property of NSC "Institute of Experimental and Clinical Veterinary Medicine") [9-12]. 
Mycotoxicological studies were performed following the guidelines "Simultaneous determination of mycotoxins (aflatoxin B1, zearalenone, patulin, sterigmatocystin) in feed and cereals by thin-layer or liquid chromatography", which were developed in the laboratory and approved by the State Committee of Veterinary Medicine of Ukraine (protocol №1, December 24, 2009).

Research results. During mycological monitoring in 2018-2019, 87 samples of feed and feed materials for cattle were studied, in particular: roughage and succulent feed (silage, haylage, hay, straw, mono-feed, beet pulp, beer pellets) -56 samples, compound feed -17 , cereals (grain mixture, corn, barley, wheat) -8 and other types of feed -6 (Fig. 1). From the data shown in Fig. 1, it is seen that mostly coarse and succulent feeds, as well as compound feeds were subjected to mycological analysis.

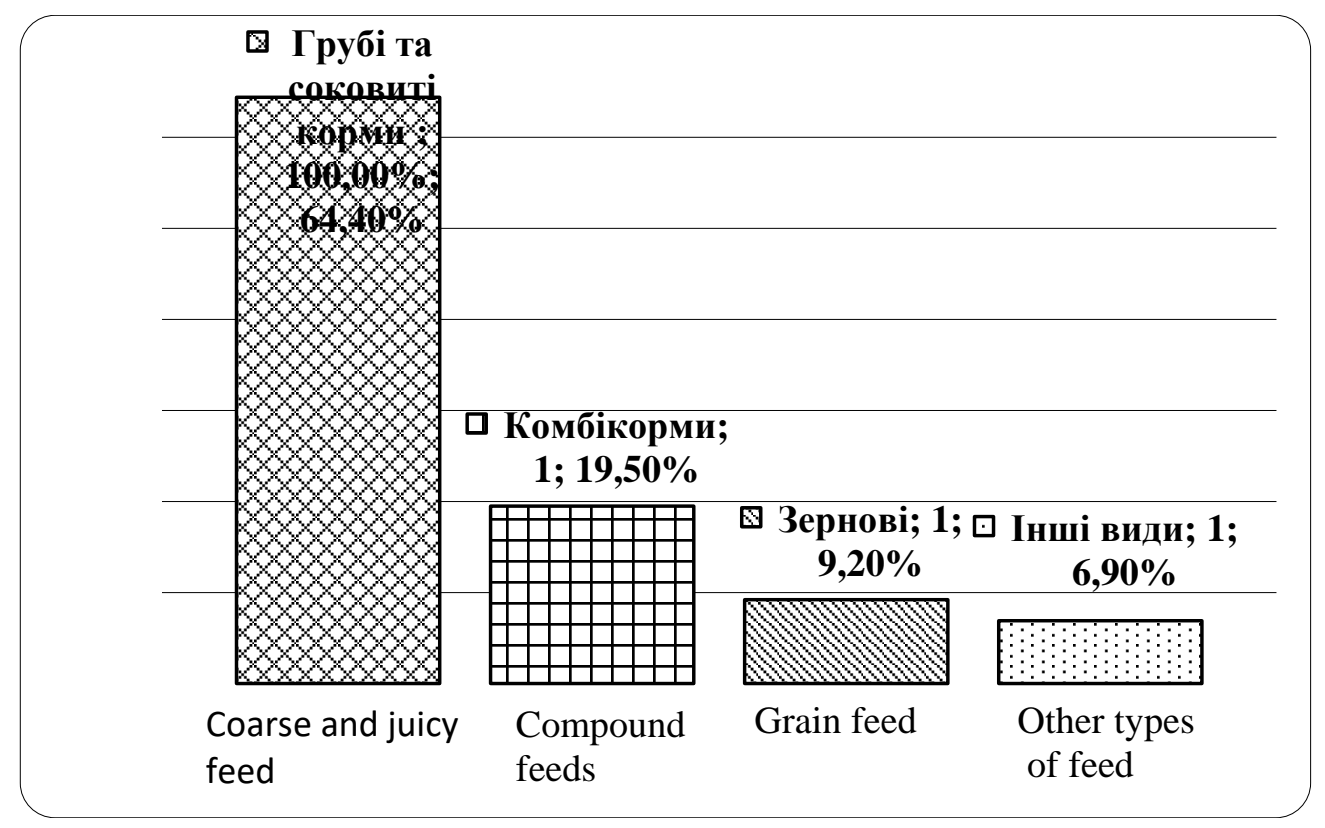

Fig. 1. Types of feed for cattle, subjected to mycological research in 2018 and the first half of 2019: 1 - roughage and succulent feed; 2 - compound feeds; 3-grain feed; 4-other types of feed

The degree of contamination with microscopic fungi of feed for cattle was determined. It was found that in 2018 and the first half of 2019 , only 26.7 and $26.2 \%$ of feeds had a permissible degree of contamination (less than $5 \cdot 10^{4}$ spores per $1 \mathrm{~g}$ of feed), and -73.3 and $73.8 \%$ of feeds exceeded the maximum allowable level (MAL),respectively [8]. Compound feeds $-23.4 \%$ (15 samples), mono-feeds and silage $18.7 \%$ (12 samples each), roughage: straw $-10.9 \%$ ( 7 samples), hay $-7.8 \%$ ( 5 samples) were the most contaminated with micromycetes.

Among the studied, the smallest number of feed samples exceeding the MAL was found among cereals $3.1 \%$ ( 2 samples). To determine the composition of mycobiota of feed and feed raw materials in 2018 and the first half of 2019, 360 isolates of mold and yeast-like fungi were isolated and identified (in 2018 - 163, in 2019 197 isolates) (Fig. 2). 

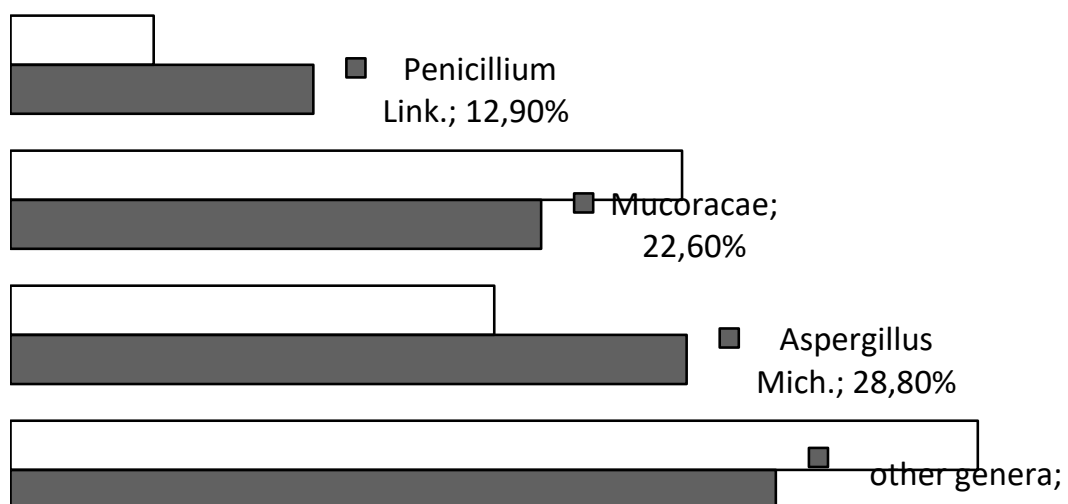

$32,60 \%$

Fig. 2. Generic composition of mycobiota of feed and feed materials for cattle in 2018 and the first half of 2019: - 2019;

$-2018$

In particular, the number of Aspergillus Mich. isolated during the study period was 89 isolates $(24.7 \%)$, Penicillium Linc. - 34 (9.5\%), Fusarium Linc. - 12 (3.3\%), family Mucoraceae - 92 isolates (25.6\%).

Representatives of other genera -133 isolates $(36.9 \%)$. It should be noted that the number of isolates of the genus Aspergillus Mich. was higher in 2018. This is due to heat and dryness in early summer of that year (temperatures in June reached $30-35^{\circ} \mathrm{C}$ ), and such climatic conditions are optimal for the growth of many species of micromycetes of the genus Aspergillus Mich.

The number of isolates of the Mucoraceae family was also identified in a clear dependence on weather conditions (temperature and humidity). In particular, due to the cool, rainy weather in July 2019, the number of isolates increased 1.5 times compared to the previous year (in $2018-37$, in $2019-55$ isolates). The taxonomic affiliation of isolates of potentially toxin-forming microscopic fungi was determined (table).

Species taxonomy of toxin-forming micromycetes isolated from feed samples for cattle in 2018 and the first half of 2019

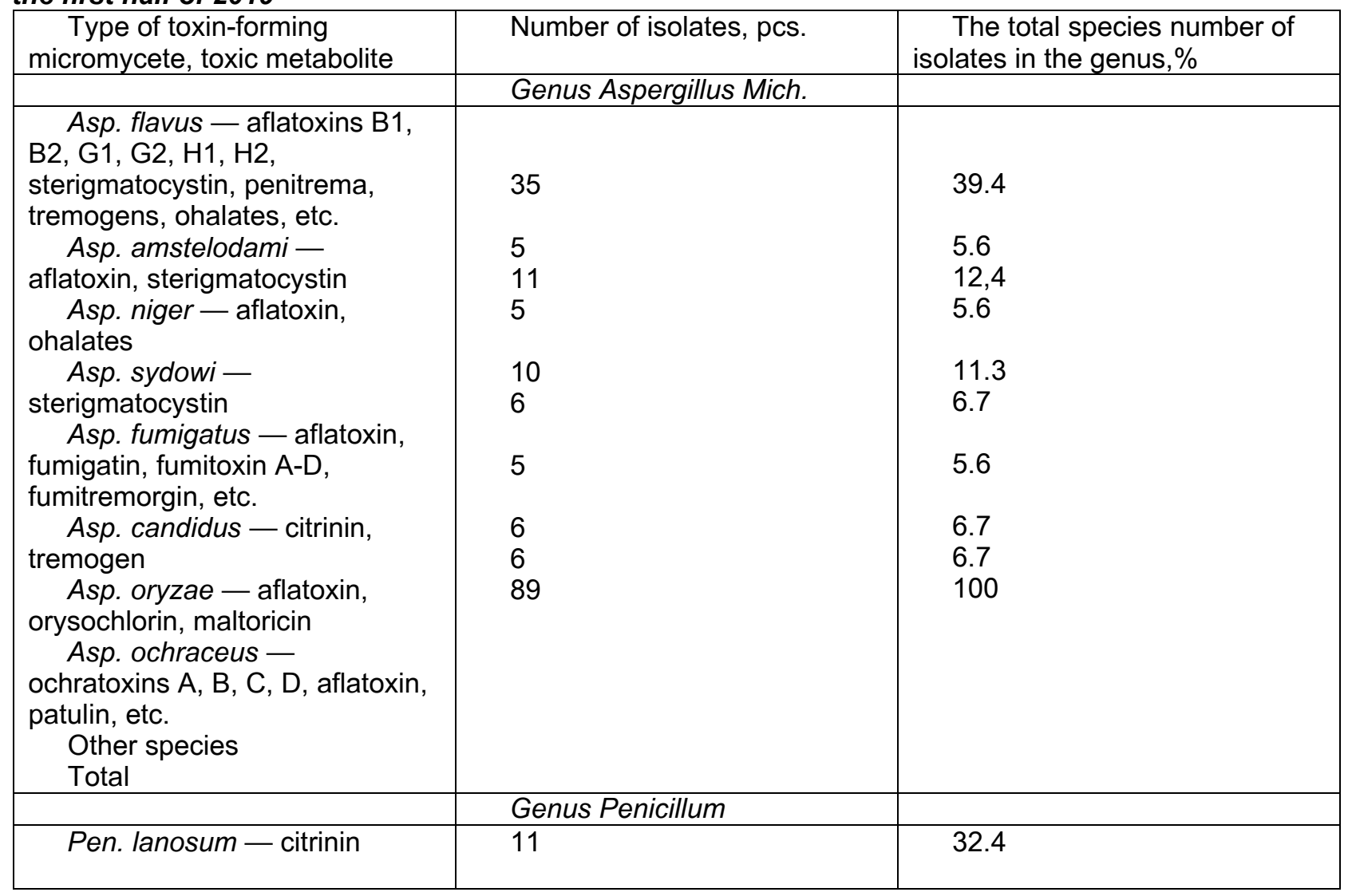




\begin{tabular}{|c|c|c|}
\hline $\begin{array}{l}\text { Pen. commune - ochratoxin, } \\
\text { penitrem, aflatoxin, etc. } \\
\text { Pen. stoloniferum - penicilic } \\
\text { and mycophenolic acids } \\
\text { Pen. casei - toxic properties } \\
\text { Other species } \\
\text { Total }\end{array}$ & $\begin{array}{l}8 \\
5 \\
2 \\
8 \\
34\end{array}$ & $\begin{array}{l}14.7 \\
5.9 \\
23.5 \\
100\end{array}$ \\
\hline & Family Mucoraceae & \\
\hline $\begin{array}{l}\text { Genus Mucor Mich. - toxic } \\
\text { properties }\end{array}$ & 34 & 37.0 \\
\hline $\begin{array}{l}\text { Genus Rhizopus Ehrenb. - } \\
\text { aflatoxin, toxic properties } \\
\text { Other species } \\
\text { Total }\end{array}$ & $\begin{array}{l}42 \\
16 \\
92\end{array}$ & $\begin{array}{l}45.6 \\
17.4 \\
100\end{array}$ \\
\hline & Genus Fusarium Linc. & \\
\hline $\begin{array}{l}\text { Fusarium moniliforme - } \\
\text { moniliformin, vomitoxin, T-2 } \\
\text { toxin, etc. } \\
\text { Fusarium moniliforme, var. } \\
\text { lactis - fusaric acid, vomitoxin, } \\
\text { moniliformin, T-2 toxin, etc. } \\
\text { Other species } \\
\text { Total }\end{array}$ & $\begin{array}{l}2 \\
3 \\
12\end{array}$ & $\begin{array}{l}16.7 \\
25 \\
100\end{array}$ \\
\hline
\end{tabular}

It was found that the main contaminant of feed was mold of the genus Aspergillus Mich., from which species: Asp. flavus, Asp. amstelodami, Asp. niger, Asp. sydowi, Asp. fumigatus, Asp. candidus, Asp. oryzae, Asp. ochraceus were identified. They were most often isolated from compound feeds, mono-feeds, silage, haylage, hay, corn, grain mixtures. The genera Mucor and Rhizopus were identified in compound feeds, mono-feeds, wheat, sunflower, straw, hay, and silage.

From micromycetes of the genus Penicillium Linc. most often species Pen. lanosum, Pen. commune, Pen. stoloniferum were found in compound feeds, haylage, hay, grain mixtures, corn, straw. The genus Fusarium Linc. species Fusarium moniliforme, Fusarium moniliforme, var. lactis were isolated from mono-feeds, compound feeds, grain mixtures, corn, barley.

According to mycotoxicological studies, 35 samples of feed with the highest degree of contamination by microscopic fungi, the presence of aflatoxin B1, zearalenone, sterigmatocystin and patulin were established within the regulated indicators in accordance with the requirements of the "List of maximum levels of undesirable substances in feeds" (The Order of the Ministry of Agrarian Policy and Food of Ukraine № 131 dated 19.03.2012, as amended by the order of the Ministry of Economic Development and Trade № 550 dated 11.10.2017).

However, in the feed sample obtained from the dairy farm of Kharkiv region, the presence of zearalenone was determined at a concentration of $0.88 \mathrm{mg} / \mathrm{kg}$, that is $76 \%$ higher than the MAL of this toxin [8]. Thus, it was established that during the mycological monitoring of 87 samples of feed and feed materials used for feeding cattle in 2018 and the first half of $2019,73.6 \%$ of feeds were of poor quality, that is more than two thirds of the total.

According to our data obtained in previous years, this trend has been continuing for the last 4 years. Thus, if in 2014 and 2015 substandard feed by the degree of contamination with microscopic fungi was $51-52 \%$, in 2016 it was already $79 \%$, and in $2017-88 \%$ [13-15]. Due to the weather conditions in 2019, for the first time in recent years, the main contaminants of feed were micromycetes of the family Mucoraceae $(25.6 \%)$ and the family Aspergillus Mich. (24.7\%) [16].

Also, due to the high content of zearalenone in the feed sample, special attention should be paid to the members of the family Fusarium Linc. Although a relatively small number of them was isolated -12 isolates $(3.3 \%)$, but they led to toxin formation. Toxin-forming taxa of micromycetes of the following species were identified: Asp. flavus, Asp. amstelodami, Asp. niger, Asp. sydowi, Asp. fumigatus, Asp. candidus, Asp. oryzae, Asp. ochraceus, Pen. lanosum, Pen. commune, Pen. stoloniferum, Fusarium moniliforme, Fusarium moniliforme, var. lactis.

\section{Conclusions}

When determining the degree of cattle feed contamination with microscopic fungi in 2018 and the first half of 2019 , it was found that $73.6 \%$ (73.3\% in 2018, $73.8 \%$ in 2019) of feed was of poor quality. The main contaminants of feed were mold saprophytes of the family Mucoraceae $-25.6 \%$ and the genus Aspergillus Mich. - 24.7\%, representatives of the genus Penicillium Linc. were 9.5\%, Fusarium Linc. - 3.3, other genera $36.9 \%$. 
Toxin-forming taxa of micromycetes were represented by species Asp. flavus, Asp. amstelodami, Asp. niger, Asp. sydowi, Asp. fumigatus, Asp. candidus, Asp. oryzae, Asp. ochraceus, Pen. lanosum, Pen. commune, Pen. stoloniferum, Fusarium moniliforme, Fusarium moniliforme, var. lactis. During mycotoxicological studies of 35 feed samples in the 1st feed sample showed the presence of zearalenone at a concentration of $0.88 \mathrm{mg} / \mathrm{kg}$, which is $76 \%$ higher than the MAL.

Aflatoxin B1, sterigmatocystin, patulin and zearalenone in other test samples were outside the detection of the method and below the MAL. This trend persisted during 2014-2017, the degree of contamination with microscopic fungi of substandard feed was 51-88\%. Prospects for further research are the systematic control of contaminants of biotic origin (micromycetes, mycotoxins) of feed materials and feeds used for feeding cattle, to prevent their negative impact on animal health and productivity and reduce economic losses in livestock.

\section{References}

1. Vasianovych, O. M., Ruda, M. le., \& Yanhol, Yu. A. (2017). Vstanovlennia vydovoi prynalezhnosti mikromitsetiv ta vyvchennia yikh zdatnosti produkuvaty fuzariotoksyny [Determination of the species of micromycetes and study of their ability to produce fusariotoxins]. Veterinary biotechnology, 30, 34-39. [In Ukrainian]

2. Abraskova, S. V., Shashko, Yu. K., \& Shashko, M. N. (2013). Biologicheskaya bezopasnost kormov [Biological safety of feed]. Minsk: Belarusian Science. [In Russian]

3. Brulevich, V. V. (2016). Bezpechnist kharchovykh produktiv za zakonodavstvom Ukrainy ta Yevropeiskoho Soiuzu [Food safety under the legislation of Ukraine and the European Union]. Judicial appeal, 2 (43), 75-83. [In Ukrainian]

4. Bilay, V. I., \& Pidoplichko, N. M. (1970). Toksinobrazuyushchie mikroskopicheskie griby $i$ vyzyvaemye imi zabolevaniya cheloveka $i$ zhivotnykh [Toxin-forming microscopic fungi and caused by they are diseases of humans and animals]. Kiev: Scientific thought. [In Russian]

5. Akhmadyshin, R. A., \& Kanarskiy, A. V. (2007). Mikotoksiny - kontaminanty kormov [Mycotoxins are feed contaminants]. Bulletin of Kazan Technological University, 2, 88-103.

6. Tell, L. A. (2005). Aspergillosis in mammals and birds: impact on veterinary medicine. Med Mycol. May, 43 (1), 71-73. doi: 10.1080/13693780400020089.

7. Kutsan, O. T., Yaroshenko, M. O., Shevtsova, H. M., \& Zhukova, I. O. (2012). Mikotoksykolohichnyi monitorynh kormiv dlia velykoi rohatoi khudoby ta svynei Pivnichno-skhidnoho rehionu Ukrainy [Mycotoxicological monitoring of feed for cattle and pigs of the North-Eastern region of Ukraine]. Problems animal engineering and veterinary medicine, 24 (2), 267-273. [In Ukrainian]

8. Obrazhei, A. F., Pohrebniak, L. I., \& Korzunenko, O. F. (1998). Metodychni vkazivky po sanitarnomikolohichnii otsintsi ta polipshenniu yakosti kormiv: metod. vkazivky. Zatverdzheni Derzh. Departamentom vet. medytsyny Ministerstva APK Ukrainy [Methodical instructions for sanitary-mycological evaluation and improvement of feed quality: method. instructions. Approved by the State. Department of Veterinary Medicine of the Ministry of Agriculture of Ukraine]. (Vol. 15 - 14/73). Kyiv.

9. Perelik maksymalno dopustymykh rivniv nebazhanykh rechovyn u kormakh ta kormovii syrovyni dlia tvaryn. Zatverdzheni Nakazom Ministerstva ahrarnoi polityky ta prodovolstva Ukrainy № 131 vid 19.03.2012, u redaktsii nakazu Ministerstva ekonomichnoho rozvytku i torhivli № 550 vid 11.10.2017. (2017). [List of maximum permissible levels of undesirable substances in animal feed and feed. Approved by Order Ministry of Agrarian Policy and Food of Ukraine No. 131 of March 19, 2012, in the version of the order of the Ministry of Economic Development and Trade No. 550 dated October 11, 2017]. [In Ukrainian]

10. Bilay, V. I. (1977). Fuzarii [Fusaria]. Kiev: Scientific thought. [In Russian]

11. Pidoplichko, N. M., \& Milko, A. A. (1971). Atlas mukoralnykh gribov [Atlas of Mucoral Mushrooms]. Kiev: Scientific thought. [In Russian]

12. Pidoplichko, N. M. (1972). Penitsillin: opredelitel [Penicillin: a determinant]. Kiev: Scientific thought. [In Russian]

13. Bilay, V. I., \& Koval, E. Z. (1988). Aspergilly: opredelitel [Aspergillus: determinant]. Kiev: Scientific thought. [In Russian]

14. Yaroshenko, M. O., Shevtsova, H. M., \& Balym, Yu. P. (2013). Monitorynh kontaminantiv biotychnoho pokhodzhennia u kormakh dlia silskohospodarskykh tvaryn Pivnichno-skhidnoho rehionu Ukrainy za 2012 rik [Monitoring of contaminants of biotic origin in farm animal feed in the Northeast Region of Ukraine for 2012]. Veterinary medicine, 97, 500-502. [In Ukrainian]

15. Yaroshenko, M. O. (2016). Plisenevi saprofity - biotychni kontaminanty kormiv yak mozhlyve dzherelo mikoziv silskohospodarskoi ptytsi [Mildew saprophytes - biotic contaminants of forage as a possible source of poultry mycosis]. Veterinary medicine, 102, 235-240. [In Ukrainian]

16. Yaroshenko, M. O., Kutsan, O. T., \& Orobchenko, O. L. (2018). Monitorynh kormiv dlia VRKh molochnoho napriamu produktyvnosti na naiavnist plisenevykh mikromitsetiv u hospodarstvakh Pivnichno-Skhidnoho rehionu Ukrainy [Monitoring of feed for cattle dairy productivity direction for the presence of mold micromycetes in the farms of the North-Eastern region of Ukraine]. Veterinary biotechnology, 32, 602-610. [In Ukrainian] 